\title{
The Project-based Learning Management Process for Vocational and Technical Education
}

\author{
Prachyanun Nilsook ${ }^{1}$, Pinanta Chatwattana ${ }^{1} \&$ Thapanee Seechaliao ${ }^{2}$ \\ ${ }^{1}$ King Mongkut's University of Technology North Bangkok, Bangkok, Thailand \\ ${ }^{2}$ Mahasarakham University, Mahasarakham, Thailand \\ Correspondence: Pinanta Chatwattana, King Mongkut's University of Technology North Bangkok, Bangkok, \\ Thailand. Tel: 66-811-744-881. E-mail: pinanta.c@ cit.kmutnb.ac.th
}

\author{
Received: January 27, $2021 \quad$ Accepted: February 14, $2021 \quad$ Online Published: February 21, 2021 \\ doi:10.5539/hes.v11n2p20 URL: https://doi.org/10.5539/hes.v11n2p20
}

\begin{abstract}
This research is an analysis and a synthesis of research papers and case studies concerning the project-based learning management. The brainstorming among experts as well as their opinions on learning management process are utilized to define an appropriate learning process for students in vocational and technical education in Thailand. The results of this research reveal that the project-based learning management process for vocational education consists of 5 steps, i.e. preparation, topic definition, creation and test, presentation, and evaluation. This is compliant with the concepts of experts, aligning the teacher and student roles in the same direction, which can be used as a learning management process as to the vocational curricula. Thus, the project-based learning management is an approach of instructional management that is in consistence with the development of vocational students in Thailand. The objective thereof is to provide learners with skills in creating inventions and innovations in the form of projects. Also, learners are encouraged to have attributes and skills of presentation, talk and communication with others, originality, critical thinking, creative thinking, and ability to work well with others; all of these are in accordance to the $21^{\text {st }}$ century skills.
\end{abstract}

Keywords: project-based learning, learning management process, vocational and technical education, instructional management, $21^{\text {st }}$ century skills, vocational curricula

\section{Introduction}

Vocational education is considered an important educational management in Thailand due to the high demand of personnel with vocational and technical education every year. Thailand's economic expansion relies heavily on foreign investment, which requires a lot of skilled labor. As a consequence, vocational education graduates are deemed as important workforce to develop the country (Chalapati \& Chalapati, 2020). Vocational education management places an emphasis on practical operations, especially those in the real workplaces. Thus, learners must be well prepared to have practical skills before going to the labor market. Education management, in which a normal system and a system with real practice are simultaneously developed, is an effort the government has determined to achieve successfully (Mongkhonvanit, 2017). Meanwhile, the youth in vocational education, who are expected to be the future workforce, cannot yet be developed in terms of learning skills and innovations; so it is quite difficult to keep up with the changes in the industry era 4.0 (Puriwat \& Tripopsakul, 2020). The economic growth of the country is continuing while the education system is being doubted in the quality (Michel, 2015).

The most important persons to make a change and provide students with active learning are teachers (Chan-o-cha, 2015). However, if teachers still stick to the same teaching methods, no matter how much the world changes, children can hardly catch up with it. UNESCO (UNESCO, 2017), an organization that ranks international education, has suggested that educational policy makers should be teachers, and merely good teachers can bring about high-quality education. Teachers must be the ones who design and facilitate learning in order that students can learn by means of practical operations. And then learning shall take place by itself within their mind and brain. Accordingly, learning from experiences will be meaningful and useful thanks to the contents derived therefrom (Dina, Michal, Musa \& Etty, 2020). The instructional management designed and facilitated by teachers, in which learners are allowed to take actions, is called project-based learning. And in order to align with the era of digital economy, it is imperative to integrate it with the $21^{\text {st }}$ century skills, which 
will eventually achieve the objectives of education. Vocational teachers, therefore, must possess updated knowledge and understanding about instructional management in accordance with the current era, particularly the knowledge and understanding about project-based learning management. In addition to the motivation of teaching, teachers must be persuaded to have a clear understanding of steps and processes of project-based learning (Stellmacher, Ohlemann, Pfetsch \& Ittel, 2020).

\section{Literature Review}

\subsection{Project-based Learning}

The concept of project-based learning management is created on the basis of philosophy of Experimentalism initiated by John Dewey, who promoted and supported the idea of learning by doing. The philosophy of such education style encourages learners to learn from the real practices. In contrast to being told or heard by others, learning from real experiences that happen directly to learners will last forever within them (Condliffe et al., 2017). This approach further results in another two concepts of education management. The first one is Constructivism, in which students are believed to be able to create knowledge by themselves. The other one is Constructionism, which believes that students can create things by themselves. Thus, in reference to learning management, it can be clearly seen that the project-based learning is influenced by the concepts and philosophies of Experimentalism, Constructivism, and Constructionism (Eckardt, Craig \& Kraemer, 2020).

Project-based learning management is sometimes called in different ways, such as project-based learning, project-based instructional management, or project-based teaching and learning. Nevertheless, what they all shares is the similar description. The Office of the Education Council (Office of the Education Council, 2014) describes project-based learning as a process of seeking knowledge or answers, which are doubted among the students, by means of different methods. Thereby, the said methods of learning are on the basis of their own interests or mutual decisions of their groups, with an attempt to obtain a piece of work of which the study results can be practically applied in real life.

Project-based Learning (PjBL) refers to the instructional management that emphasizes practical experiences of learners, enabling them to learn how to solve problems, have creative thinking at work, know how to plan their work by means of scientific methods, communicate and work well with others, and evaluate their own works and operations. There is another learning technique that has the same abbreviation as Project-based Learning, i.e. Problem-based Learning, with an abbreviation PBL. Therefore, when referring to project-based learning, the English abbreviation is defined as PjBL (Dole, Bloom \& Doss, 2016; Ralph, 2016; Mitchell \& Rogers, 2020) for differentiation, and it is generally accepted (Stanton, Guerin \& Barrett, 2017).

The difference between project-based learning and general projects assigned by teachers is that the former is a learner-centered learning process, in which steps are designated for learners to achieve self-learning and collaborative learning. The groups referred herein can be formed in any ways (José, John \& Adam, 2020). On the other hand, the general projects are considered assignments that students or groups of students have to undertake according to different subjects in their curriculum. In the project-based learning, the assigned projects are concerning circumstances in real life. Students are given opportunities to study and take action by themselves under the teachers' supervision and counseling in terms of ideas of projects, action plans, designs, operation, and presentation of the projects. Teachers may also provide transdisciplinary learning, which can further create greater experiences for learners (Vogler et al., 2018).

\subsection{Integration of the $21^{\text {st }}$ Century Skills}

The Partnership for $21^{\text {st }}$ Century Skills or P21, has developed a vision for student's success within the context of teaching knowledge of core subjects. Students must learn such essential skills as critical thinking, problem solving, creative thinking, communication, and collaboration (Abdulkadir, Husamah \& Ahmad, 2019). The above conceptual framework requires necessary educational support systems, e.g. learning standards, evaluation, curriculum and teaching methods, professional development, and learning atmosphere that encourages students have more participation in learning process (Viro, Lehtonen, Joutsenlahti \& Tahvanainen, 2020). According to the conceptual framework of the $21^{\text {st }}$ century skills (Partnership for $21^{\text {st }}$ Century Skills, 2008), the guidelines for developing learner's skills in each area are summarized as below:

- The $21^{\text {st }}$ century main contents and living skills: Possession of knowledge concerning the core subjects is important and essential to students' success. The three core subjects consist of Reading, Writing and Arithemetics, all of which cover a variety of subjects, such as English, reading, world's languages, art, mathematics, economics, science, geography, history, good governance and citizenship. Nonetheless, this is not sufficient in order to live in the era of $21^{\text {st }}$ century. Therefore, schools must promote a high level of 
understanding of academic content by integrating the following $21^{\text {st }}$ century life skills in all major subjects: Global Awareness, Financial/Economic/Business and Entrepreneurial Literacy, Civic Literacy, Health Literacy, and Environment Literacy.

- Learning and innovation skills: Learning and innovation skills are a benchmark of student preparedness before entering career life which is more and more complicated in today's world. The said skills include Creativity and Innovation, Critical Thinking and Problem Solving, and Communication and Collaboration.

- Information skills, media, and technology: Today, we live in an environment that is propelled by media and technology. This can be seen from the ability to access a huge amount of information, the rapid change in education technology and its interrelation, and the engagement at an unprecedented rate. Efficient citizens and workers must be able to demonstrate critical thinking skills and perform a variety of tasks, such as Information Literacy, Media Literacy, and Information, Communication and Technology Literacy.

- Life and career skills: At present, life and work conditions require a wide range of knowledge and cognitive skills. The ability to work amidst the competition of information and to live among the complicated conditions can eventually lead to success. It is necessary that students take more attention to develop the following life skills, i.e. Flexibility and Adaptability, Initiative and Self-direction, Social and Cross-Cultural Skills, Productivity and Accountability, and Leadership and Responsibility.

- The support systems for $21^{\text {st }}$ century learning: The development of a comprehensive conceptual framework for the 21 st century learning requires more support systems that are created on the basis of specific skills, knowledge, expertise, and learning abilities. This is to enable students to be well-educated and equipped with a variety of essential skills. P21 has identified the following 5 systems that encourage students to acquire the $21^{\text {st }}$ century skills, i.e. $21^{\text {st }}$ Century Standards, Assessments of $21^{\text {st }}$ Century Skills, $21^{\text {st }}$ Century Curriculum and Instruction, $21^{\text {st }}$ Century Professional Development, and $21^{\text {st }}$ Century Learning Environments.

The standards for project-based learning in the $21^{\text {st }}$ century will be integrated with $4 \mathrm{C}$ : Critical Thinking, Collaboration, Communication, and Creativity. This means that the results of project-based learning will lead to critical thinking, collaboration, communication, and creativity (Dag \& Durdu, 2017). The integration of project-based learning and $21^{\text {st }}$ century skills is directly related to each other because, during the project, students are encouraged to use the skills of critical thinking, creativity, problem solving, as well as collaboration (Warr \& West, 2020). Especially in vocational education, students are required to work in the real workplaces, which is believed to be an appropriate stage coupled with learning in their class. Self-learning will also help increase confidence with assistance from experts (Macleod \& Veen, 2020).

\subsection{Project-based Learning and Vocational Education in Thailand}

Project-based learning management is one of the approaches that focus mainly on learners. It is in accordance with the National Education Act, placing an emphasis on thinking process skill, inquiry skill from various learning sources, practical training, and knowledge application, in order to prevent and solve problems. Project-based learning process according to the guidelines of the Office of the National Education Commission (Office of the National Education Commission, 2014) consists of 4 main steps: presentation, planning, action and evaluation. Thereby, the activities for both instructors and learners are designed differently at different stages.

Vocational education institutes have policies of project-based learning, in which the guidelines are clearly identified in the form of 3 main steps, i.e. planning, action, and investigation (Bureau of Vocational and Professional Standards, 2012). In particular, Science-Based Technology Vocational College requires that the instruction should be based on projects and learner's competency must be measured. The project-based learning management process in Science-Based Technology Vocational College consists of 5 stages and all of them are related to one another, i.e. open up for concepts, search for possibilities, selection of desired topics, creation and test, and professional presentation. Therefore, there ought to be project-based instructional management in colleges (Wu, Warschauer, Fischer \& Washington, 2020). In several technical colleges, the project-based instructional management is integrated in all subjects, with a learning style that promotes wisdom-based creativity or Constructionism. The courses are developed into the form of free elective subjects designated for students of every year level. Meanwhile, Ban Khai Technical College requires that students who are about to graduate must carry out a project in conjunction with the workplaces, generating work pieces that can be put in practical use. Accordingly, the workplaces shall be satisfied and the colleges shall have been assessed for quality based on the provided standards. All of the aforementioned represents the importance of project-based learning at policy level, school level, teacher and Learner level (Office of Vocational Education Commission, 2015). 
There are several methods in the process of creating a project. The ingenious strategies can promote the $21^{\text {st }}$ century skills, especially the promotion of thinking skills through the 5 stages of project implementation, i.e. identifying project questions, planning about the project, project implementation, data analysis and interpretation, and summary and evaluation (Hanif, Fany, Wijaya \& Winarno, 2019). This is consistent with the development of the learners of new generation. In reference to project-based teaching and research-based teaching, the procedures thereof are quite the same, starting from grievance, doubt, and curiosity, and then leading to the formulation of research issues or project topics, methodology, hypothesis, and scope of study, in order to collect data, record experimental study results, perform data processing and analysis, and summarize the results of research or study with discussions (Mentzer, Frydenberg \& Yates, 2020). Thus, research-based teaching is integrated into project-based teaching because the presentation of the project results in the form of a report is always written in a research style. Therefore, project-based learning is considered a technique that can be integrated well with a variety of teaching methods.

Vocational education management has placed great priority on project-based learning, setting it out as a policy for instructional management of vocational education. Particularly when the curriculum was revised in 2014, the guidelines for development and application of curriculum among education institutes required that the implementation of a project must be integrated in learning management in each semester (Bureau of Vocational and Professional Standards, 2012). It is a kind of learning management that allows learners to take action in a format of study, survey, research, experiment, and invention. At the meantime, teachers shall assist the students in terms of facilitation, advice, learning process design, and encouragement, so as to have the project accomplished. There are 6 steps in the project-based instructional management (Nuntasukon \& Yuthong, 2014) as follows:

- Step 1 Preparation: Instructors provide the scope of project and the sources of information by means of identifying them and leading questions in the learning management plan.

- Step 2 Topic definition and selection: The group of learners jointly find out topics for the project, study the possibilities of each topic for selection, and present the said topic to the instructors for approval.

- Step 3 Project layout: Students study the scope of the project and search for sources of information. Then they jointly plan the project implementation by specifying activities in each step, roles and responsibilities as well as workload of group members, and duration of the operation.

- Step 4 Project implementation: The members of the group carry out their tasks and responsibilities as provided in the plan by integrating their knowledge and skills while exchanging experiences and discovering new knowledge. Thereby, instructors are available for assistance, giving advice or solving problems together with the students.

- Step 5 Presentation: Learners summarize the operation results, prepare a report and present the results of their project in order to exchange knowledge with other groups.

- Step 6 Evaluation: Instructors evaluate the project results in a continuous manner by means of varied methods and tools, focusing on authentic assessment, for instance, on knowledge, process, results, behaviors, and characters of learners.

The project-based learning management with 6 steps as mentioned above is similar to the project-based concept for vocational learners called V Model (Basjaruddin \& Rakhman, 2016), which was adapted to V-Project Based Learning with the following 5 steps (Po-ngen, Pratumsuwan \& Hutamarn, 2014):

- Step 1 Preparation: Instructors prepare the scope of project, sources of information, and leading questions. All of these can be presented in a variety of formats such as text, video clip, or online news.

- Step 2 Study of possibilities: Students study the scope of the project and sources of information, and search for sources from various websites. The data derived therefrom are exchanged among group members with an attempt to answer the leading questions provided by instructors. The exchange of information can be done through such asynchronous communication tools as group discussion board, wiki, or via synchronous tools like chat or web conference. Then students begin to study the possibilities of the project.

- Step 3 Topic definition: Group discussion is conducted to find out a topic for the project. After instructors agree to the topic of the group, learners in each group start to plan the project implementation by specifying activities in each step and operation schedule. Roles and responsibilities of group members are clearly defined based on their convenience. After that, the summary shall be presented to instructors again.

- Step 4 Creation and test of work piece: Group members carry out their tasks and responsibilities as to their 
knowledge to create a work piece. Then they share new experiences and knowledge with group members, which can be done in synchronous and asynchronous manners according to the convenience of group members. This is accompanied by instructors' advice. After accomplishing the invention, the work piece must be tested to measure its effectiveness.

- Step 5 Presentation: Students prepare a report and presentation that can illustrate the project results, their work, and process. And then the said presentation is showcased through different online tools such as video clip, online text, webpage, blog, facebook, etc.

Accordingly, this research is considered a study of project-based instructional management process for vocational and technical education with an intention to find out the guidelines for project-based learning management at an international level. The process is synthesized in accordance with project-based learning management in the context of Thailand with an integration of learning in line with the $21^{\text {st }}$ century skills so that vocational learners have desired characteristics that satisfy the demands and policies of the country.

\section{Methodology}

Once conducting document research and focus group discussion about relevant principles and theories, project-based learning management of Thai and foreign scholars, teaching methods and techniques of Thai educational institutes in primary, secondary, tertiary and vocational levels, the researchers could synthesize the said principles and methods into a project-based learning management process for vocational and technical education in Thailand. And then this was brought into a brainstorming discussion with experts specialized in the fields of vocational education and project-based instructional management, which the research results derived from document research and focus group discussion consist of synthesis matrix of project-based learning and project-based learning management process for vocational education, as shown in topic results.

\section{Results}

The research results derived from document research were put into a synthetic matrix according to a number of documents and researches related to project-based learning management, showing only corresponding parts as seen in Table 1. And then the results were converted into a diagram depicting the project-based learning management process for vocational and technical education in Thailand, as shown in Figure 1.

Table 1. Synthesis matrix of project-based learning

\begin{tabular}{|c|c|c|c|c|c|c|c|c|}
\hline Steps of project-based learning & 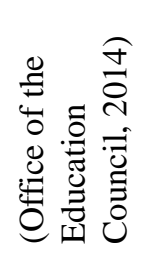 & 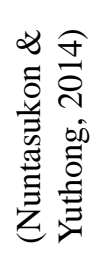 & 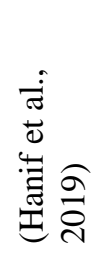 & 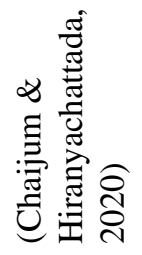 & 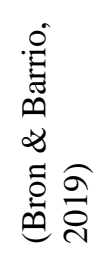 & 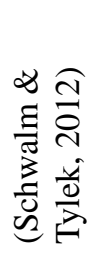 & 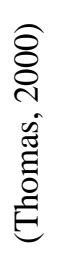 & 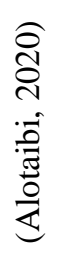 \\
\hline Preparation & & $\checkmark$ & $\checkmark$ & & $\checkmark$ & $\checkmark$ & $\checkmark$ & \\
\hline Planning & $\checkmark$ & & & $\checkmark$ & & & & $\checkmark$ \\
\hline Study of possibilities & & $\checkmark$ & $\checkmark$ & & $\checkmark$ & & $\checkmark$ & $\checkmark$ \\
\hline Topic Definition & & $\checkmark$ & $\checkmark$ & $\checkmark$ & $\checkmark$ & $\checkmark$ & & \\
\hline Creation and Test & $\checkmark$ & $\checkmark$ & $\checkmark$ & $\checkmark$ & $\checkmark$ & $\checkmark$ & $\checkmark$ & $\checkmark$ \\
\hline Data analysis and interpretation & & & & $\checkmark$ & & & $\checkmark$ & \\
\hline Presentation & $\checkmark$ & $\checkmark$ & $\checkmark$ & & $\checkmark$ & $\checkmark$ & $\checkmark$ & $\checkmark$ \\
\hline Evaluation & $\checkmark$ & $\checkmark$ & & $\checkmark$ & & $\checkmark$ & & $\checkmark$ \\
\hline
\end{tabular}

In reference to the synthesis matrix of project-based learning process in Table 1, it is evident that the widely accepted project-based learning approaches with quite similar trends consist of not many steps. Once studying in details, it is found that some synthesized steps can be combined in the same issues or topics. As a consequence, it can be concluded that project-based learning process consists of 5 steps, i.e. preparation, topic definition, creation and test, presentation, and evaluation. 


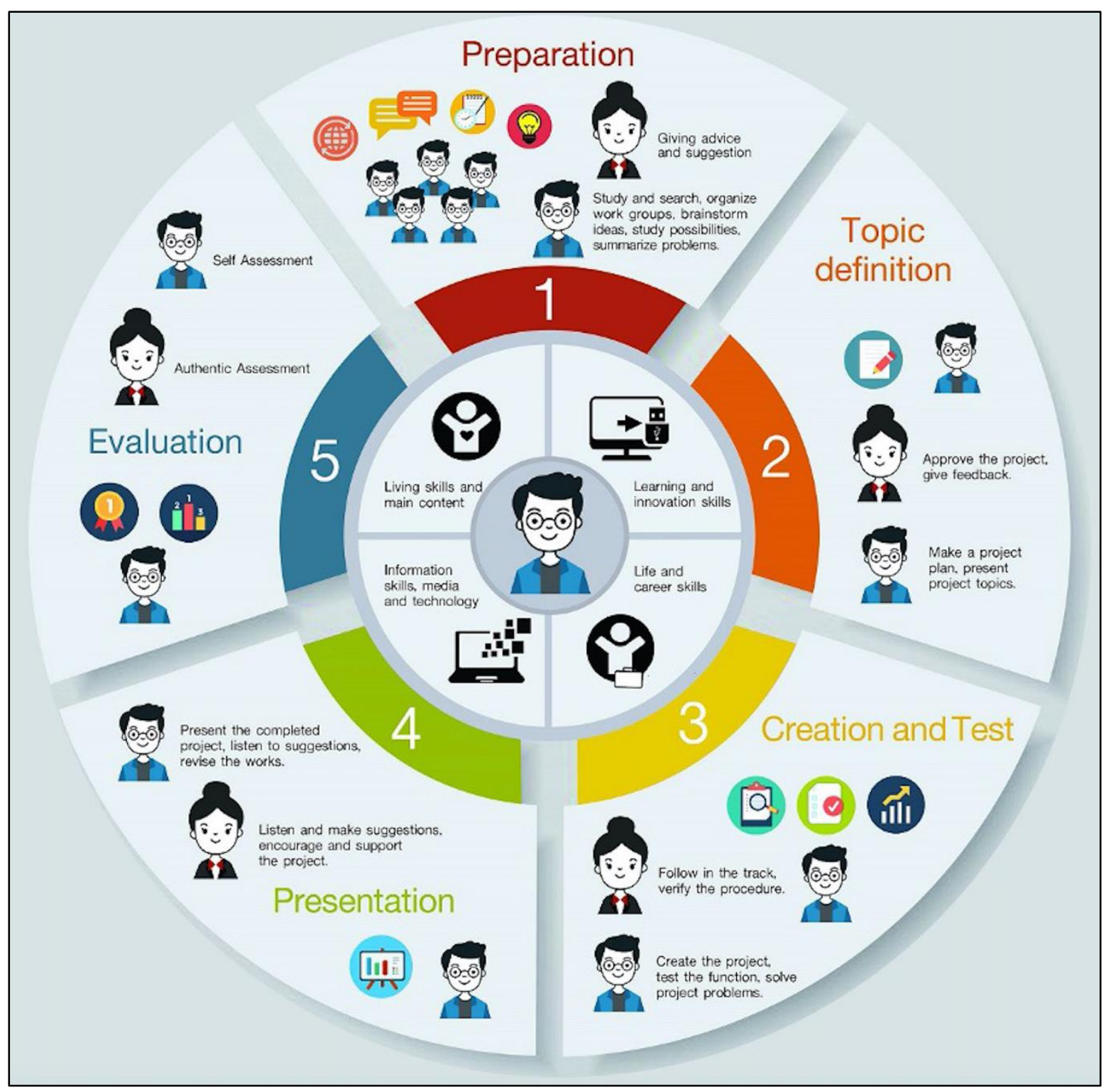

Figure 1. Project-based learning management process for vocational education

Regarding Figure 1, the results of brainstorming of the ideas towards the roles of instructors and learners in project-based learning, obtained from the experts specialized in the fields of instruction management and vocational education, the roles of instructors and learners in vocational education can be summarized as follows. Those who can make the project-based learning management successful are instructors and learners. Both instructors and learners have an important role and they must learn together. Instructors provides advice and suggestions along with the guidelines which are all useful for learners' self-learning. Learners are required to study, take action, work in groups, and collaboratively create their work in a productive manner (Yusri, 2018). This can then achieve the learning objectives that are in line with the $21^{\text {st }}$ century skills. Referring to the brainstorming, the roles of instructors and learners can be defined as below.

The focus group discussion, the results summarized by the experts as well as their opinions about relevant researches are illustrated in Table 2. 
Table 2. Brainstorming of the ideas towards the roles of instructors and learners

\begin{tabular}{|c|c|c|c|}
\hline $\begin{array}{l}\text { Steps of project-based } \\
\text { learning }\end{array}$ & $\begin{array}{l}\text { Integration of } \\
21^{\text {st }} \text { century skills }\end{array}$ & Roles of instructors & Roles of learners \\
\hline $\begin{array}{l}\text { Preparation } \\
\text { (Chaijum \& } \\
\text { Hiranyachattada, 2020; } \\
\text { Hanif et al., 2019; } \\
\text { Nuntasukon \& } \\
\text { Yuthong, 2014; } \\
\text { Thomas, 2000) }\end{array}$ & $\begin{array}{l}\text { - living skills and main content } \\
\text { - learning and innovation skills } \\
\text { - information skills, media and } \\
\text { technology } \\
\text { - life and career skills }\end{array}$ & $\begin{array}{l}\text { - prepare a learning } \\
\text { management plan in } \\
\text { accordance with the } \\
\text { course objectives } \\
\text { - provide learners with } \\
\text { orientation and } \\
\text { understanding of } \\
\text { project-based learning } \\
\text { - provide advice and } \\
\text { suggestion }\end{array}$ & $\begin{array}{l}\text { - study and search } \\
\text { - organize work } \\
\text { groups } \\
\text { - brainstorm ideas } \\
\text { - study possibilities } \\
\text { - summarize } \\
\text { problems and prepare } \\
\text { the project plan }\end{array}$ \\
\hline $\begin{array}{l}\text { Topic Definition } \\
\text { (Bron \& Barrio, 2019; } \\
\text { Nuntasukon \& } \\
\text { Yuthong, 2014) }\end{array}$ & $\begin{array}{l}\text { - living skills and main content } \\
\text { - learning and innovation skills } \\
\text { - information skills, media and } \\
\text { technology } \\
\text { - life and career skills }\end{array}$ & $\begin{array}{l}\text { - approve the project } \\
\text { - give feedback } \\
\text { - follow in the track as } \\
\text { to the steps of } \\
\text { project-based learning }\end{array}$ & $\begin{array}{l}\text { - make a project plan } \\
\text { - present project } \\
\text { topics } \\
\text { - listen to suggestions } \\
\text { and do adjustment }\end{array}$ \\
\hline $\begin{array}{l}\text { Creation and Test } \\
\text { (Chaijum \& } \\
\text { Hiranyachattada, 2020; } \\
\text { Alotaibi, 2020; } \\
\text { Thomas, 2000) }\end{array}$ & $\begin{array}{l}\text { - living skills and main content } \\
\text { - learning and innovation skills } \\
\text { - information skills, media and } \\
\text { technology } \\
\text { - life and career skills }\end{array}$ & $\begin{array}{l}\text { - follow and check the } \\
\text { operation } \\
\text { - listen to the problems } \\
\text { and make suggestions }\end{array}$ & $\begin{array}{l}\text { - create the project } \\
\text { - test the function } \\
\text { - solve project } \\
\text { problems }\end{array}$ \\
\hline $\begin{array}{l}\text { Presentation } \\
\text { (Bron \& Barrio, 2019; } \\
\text { Hanif et al., 2019; } \\
\text { Alotaibi, 2020; } \\
\text { Thomas, 2000) }\end{array}$ & $\begin{array}{l}\text { - living skills and main content } \\
\text { - learning and innovation skills } \\
\text { - information skills, media and } \\
\text { technology } \\
\text { - life and career skills }\end{array}$ & $\begin{array}{l}\text { - listen and make } \\
\text { suggestions } \\
\text { - encourage and } \\
\text { support the project }\end{array}$ & $\begin{array}{l}\text { - present the } \\
\text { completed project } \\
\text { - listen to suggestions } \\
\text { - revise the works }\end{array}$ \\
\hline $\begin{array}{l}\text { Evaluation } \\
\text { (Chaijum \& } \\
\text { Hiranyachattada, 2020; }\end{array}$ & $\begin{array}{l}\text { - present the completed project } \\
\text { - listen to suggestions } \\
\text { - revise the works }\end{array}$ & $\begin{array}{l}\text { - authentic assessment } \\
\text { - assessment together } \\
\text { with experts }\end{array}$ & $\begin{array}{l}\text { - self- assessment } \\
\text { - assessment by } \\
\text { classmates }\end{array}$ \\
\hline
\end{tabular}

Hanif et al., 2019;

Alotaibi, 2020)

\section{Discussion of the Results}

The results of this research show that project-based learning management is an important approach in an instructional management for vocational and technical education. This kind of learning is believed to create such learners that are able to learn how to create innovation, have motivation to create new things, employ scientific processes and possess strengthened ways of thinking (Tongsakul, Jitgarun \& Chaokumnerd, 2011). In addition, it paves the ways of creative collaboration among learners. No matter where learners are, they can still communicate and work together thanks to the emerging technologies that facilitate communication and cooperation in project implementation (Trilek, Piriyasurawong \& Jeerungsuwan, 2016). Learners are able to learn different processes and procedures in order to accomplish the project, and they can rely on a variety of project procedures that can be conducted easily via websites or online media (Chatwattana \& Nilsook, 2017).

The integration of project-based learning into STEM-based learning is a next guideline in the development of vocational learners. The development of inventions and innovations in the format of project shall results in work pieces, while the learning process requires assistance from an education management in the form of STEM Education, which focuses mainly on the teaching of science, technology, engineering, and mathematics. The countries with the world's top ranked education usually employ STEM education. In other words, the 4 teaching aspects above are integrated into individual subjects. It is an educational management that enables students to experience all four aspects of learning (Techakosit \& Nilsook, 2018). The integration of project-based learning, as teaching techniques, into STEM education, therefore, is considered a very suitable and coherent approach. This results in STEM Project-based Learning, in which the project-based processes are used to support the management of STEM education. This is because it is a kind of learning that truly increases learners' science skills (Kingston, 2018). So, project-based learning management can encourage learners to have real experiences, 
work on a concrete job, and receive practical skills that can be applied in daily life. It is a way of learning that is more consistent with real life than just learning from textbooks only. It is important to keep in mind that project-based learning must always be fun and it must promote learners' interest in what they are learning so that they can apply these skills in their work. Moreover, vocational students can be prevented from dropout (Sripan \& Sujivorakul, 2020).

\section{Conclusion}

Project-based instructional management is a learning process that encourages vocational learners in Thailand to have living skills in the $21^{\text {st }}$ century. Different steps can be applied to instructional management in order to promote learner-centered learning and increase efficiency of teaching and learning in classroom. Learners know how to solve problems and have critical thinking skill; meanwhile, they can create their works, which can promote their creativity, teamwork and collaborative learning skills. Also, they are able to communicate with one another with the aid of technology in the digital era, which is considered an integration appropriate to the present time. Accordingly, project-based learning is considered one of the approaches that should be integrated into instructional management, so that the skills needed for manpower development in vocational and technical education in Thailand can be eventually achieved.

The project-based learning management process for vocational education consists of 5 steps, i.e. preparation, topic definition, creation and test, presentation, and evaluation. This is compliant with the concepts of experts, aligning the teacher and student roles in the same direction, which can be used as a learning management process as to the vocational curricula.

\section{Acknowledgments}

This study was supported by The Office of Vocational Education Commission, Thailand's Ministry of Education. The authors would like to say thanks to Research Center for Vocational Education Technology, King Mongkut's University of Technology North Bangkok. (KMUTNB), the authors' colleagues from Vocational Education Supervisory Unit, technical and vocational institutes, companies, and governmental agencies that provided insight and expertise that greatly assisted the study.

\section{References}

Abdulkadir, R., Husamah., \& Ahmad, F. (2019). Hybrid-PjBL: Learning Outcomes, Creative Thinking Skills, and Learning Motivation of Preservice Teacher. International Journal of Instruction, 12(2), 179-192. https://doi.org/10.29333/iji.2019.12212a

Alotaibi, M. G. (2020). The Effect of Project-Based Learning Model on Persuasive Writing Skills of Saudi EFL Secondary School Students. English Language Teaching, 13(7), 19-26. https://doi.org/10.5539/elt.v13n7p19

Basjaruddin, N. C., \& Rakhman, E. (2016). Implementation of Project Based Learning in Mechatronic Lab Course at Bandung State Polytechnic. International Journal of Evaluation and Research in Education, 5(4), 284-291. https://doi.org/10.11591/ijere.v5i4.5955

Bron, M., \& Barrio, M. G. (2019). Project-based Learning for Teaching Transmedia Communication. Journal of Problem Based Learning in Higher Education, 7(1), 141-151.

Bureau of Vocational and Professional Standards. (2012). Project-based Learning Manual. Bangkok: The Office of Vocational Education Commission, Thailand's Ministry of Education.

Chaijum, N., \& Hiranyachattada, T. (2020). Integrated learning and project-based learning for project of electrical measurement and instrumentations in electrical engineering course. European Journal of Science and Mathematics Education, 8(1), 6-11. https://doi.org/10.30935/scimath/9543

Chalapati, N., \& Chalapati, S. (2020). Building a skilled workforce: Public discourses on vocational education in Thailand. International Journal for Research in Vocational Education and Training, 7(1), 67-90. https://doi.org/10.13152/IJRVET.7.1.4

Chan-o-cha, P. (2015). Government to Develop Thailand as an ASEAN Education Hub. Bangkok: The Government Public Relations Department, Office of the Prime Minister.

Chatwattana, P., \& Nilsook, P. (2017). A web-based learning system using project-based learning and Imagineering. International Journal of Emerging Technologies in Learning, 12(5), 4-22. https://doi.org/10.3991/ijet.v12i05.6344

Condliffe, B., Quint, J., Visher, M. G., Bangser, M. R., Drohojowska, S., Saco, L., \& Nelson, E. (2017). Project-Based Learning: A Literature Review. Mdrc, Building Knowledge to Improve Social Policy. 
Retrieved from https://files.eric.ed.gov/fulltext/ED578933.pdf

Dag, F., \& Durdu, L. (2017). Pre-Service Teachers' Experiences and Views on Project-Based Learning Processes. International Education Studies, 10(7), 18-39. https://doi.org/10.5539/ies.v10n7p18

Dina, T., Michal, G.-K., Musa, A. G., \& Etty, G. (2020). Experiences of preservice teachers exposed to project-based learning. European Journal of Teacher Education, 43(3). https://doi.org/10.1080/02619768.2019.1711052

Dole, S., Bloom, L., \& Doss, K. K. (2016). Rocket to Creativity: A Field Experience in Problem-Based and Project-Based Learning. Global Education Review, 3(4), 19-32. Retrieved from https://files.eric.ed.gov/fulltext/EJ1120599.pdf

Eckardt, P., Craig, M., \& Kraemer, L. (2020). The Impact of Project-Based Learning on Student Content Knowledge in an Undergraduate, Teacher Preparation, Foundations of Education Course. Journal for Leadership and Instruction, Spring, 38-42. Retrieved from https://files.eric.ed.gov/fulltext/EJ1255862.pdf

Hanif, S., Fany, A., Wijaya, C., \& Winarno, N. (2019). Enhancing Students ' Creativity through STEM Project-Based Learning. Journal of Science Learning, 2(2), 50-57. https://doi.org/10.17509/jsl.v2i2.13271

José, H., John, M., \& Adam, H. (2020). Project-based learning groups of friends and acquaintances: The role of efficacy beliefs. The Journal of Educational Research, 113(2), 133-144. https://doi.org/10.1080/00220671.2020.1756729

Kingston, S. (2018). Project Based Learning \& Student Achievement: What Does the Research Tell Us?. PBL Evidence Matters, 1(1), 1-11. Retrieved from https://files.eric.ed.gov/fulltext/ED590832.pdf

Macleod, M., \& Veen, J. T. Van Der. (2020). Scaffolding interdisciplinary project-based learning: a case study. European Journal of Engineering Education, 45(3), 363-377. https://doi.org/10.1080/03043797.2019.1646210

Mentzer, K., Frydenberg, M., \& Yates, D. J. (2020). Teaching Applications and Implications of Blockchain via Project-Based Learning: A Case Study. Information Systems Education Journal, 18(December), 57-85.

Michel, S. (2015). Education in Thailand: When economic growth is no longer enough. London Review of Education, 13(3), 79-91. https://doi.org/10.18546/LRE.13.3.11

Mitchell, J. E., \& Rogers, L. (2020). Staff perceptions of implementing project-based learning in engineering education. European Journal of Engineering Education, 45(3), 349-362. https://doi.org/10.1080/03043797.2019.1641471

Mongkhonvanit, J. (2017). Thailand's dual education system: a way forward. Higher Education, Skills and Work-Based Learning, 7(2), 155-167. https://doi.org/10.1108/HESWBL-09-2016-0067

Nuntasukon, P., \& Yuthong, W. (2014). Vocational Education and Application Course. Bangkok: Vocational Education Supervisory Unit, Office of the Vocational Education Commission.

Office of the Education Council. (2014). Project-based learning management. Bangkok: Ministry of Education, Thailand.

Office of the National Education Commission. (2014). National Education Act. Bangkok: Office of the Prime Minister, Thailand. Retrieved from http://planipolis.iiep.unesco.org/upload/Thailand/Thailand_Education_Act_1999.pdf

Office of Vocational Education Commission. (2015). Guidelines for Project-Based Learning. Bangkok: Ministry of Education, Thailand.

Partnership for $21^{\text {st }}$ Century Skills. (2008). $21^{\text {st }}$ Century Skills, Education \& Competitiveness. Partnership for $21^{\text {st }}$ Century Skills. Retrieved from https://files.eric.ed.gov/fulltext/ED519337.pdf

Po-ngen, W., Pratumsuwan, P., \& Hutamarn, S. (2014). Project-based Learning. Bangkok: Faculty of Technical Education, King Mongkut's University of Technology North Bangkok. Retrieved from http://www.fte.kmutnb.ac.th/km/project-based learning.pdf

Puriwat, W., \& Tripopsakul, S. (2020). Preparing for Industry 4.0 - Will youths have enough essential skills ?: An Evidence from Thailand. International Journal of Instruction, 13(3), 89-104. https://doi.org/10.29333/iji.2020.1337a

Ralph, R. A. (2016). Post secondary project-based learning in science, technology, engineering and mathematics. Journal of Technology and Science Education, 6(1), 26-35. https://doi.org/10.3926/jotse.155 
Schwalm, J., \& Tylek, K. (2012). Systemwide implementation of project-based learning: The Philadelphia Approach. Afterschool Matters, Spring, 1-8.

Sripan, T., \& Sujivorakul, C. (2020). Variables that Influence the Intention to Persist in Vocational Education. International Journal of Instruction, 13(2), 17-32. https://doi.org/10.29333/iji.2020.1322a

Stanton, M. T., Guerin, S., \& Barrett, T. (2017). Interdisciplinary Journal of Problem-Based Learning The Transfer of Problem-Based Learning Skills to Clinical Practice Problem-based Learning Special iSSue On cOmpetency OrientatiOn in prOblem-baSeD learning. Interdisciplinary Journal of Problem-Based Learning, 11(2). https://doi.org/10.7771/1541-5015.1678

Stellmacher, A., Ohlemann, S., Pfetsch, J., \& Ittel, A. (2020). Pre-Service Teacher Career Choice Motivation: A Comparison of Vocational Education and Training Teachers and Comprehensive School Teachers in Germany. International Journal for Research in Vocational Education and Training, 7(2), 214-236. https://doi.org/10.13152/IJRVET.7.2.5

Techakosit, S., \& Nilsook, P. (2018). The Development of STEM Literacy Using the Learning Process of Scientific Imagineering through AR. International Journal of Emerging Technologies in Learning, 13(1), 230-238. https://doi.org/10.3991/ijet.v13i01.7664

Thomas, J. W. (2000). A Review of Research on Project-based Learning. California: The Autodesk Foundation.

Tongsakul, A., Jitgarun, K., \& Chaokumnerd, W. (2011). Empowering Students Through Project-Based Learning: Perceptions Of Instructors And Students In Vocational Education Institutes In Thailand. Journal of College Teaching \& Learning (TLC), 8(12), 19-34. https://doi.org/10.19030/tlc.v8i12.6618

Trilek, W., Piriyasurawong, P., \& Jeerungsuwan, N. (2016). Collaborative Project-Based Learning via Augmented Reality on m-Learning Model to Enhance Basic ASEAN Community Skills for Thai and the Lao PDR Students. International Journal of Information and Education Technology, 6(10), 813-816. https://doi.org/10.7763/IJIET.2016.V6.798

UNESCO. (2017). Guidelines for the Quality Assurance of TVET Qualifications in the Asia-Pacific Region. Bangkok: UNESCO Bangkok Office.

Viro, E., Lehtonen, D., Joutsenlahti, J., \& Tahvanainen, V. (2020). Teachers' perspectives on project-based learning in mathermatics and science. European Journal of Science and Mathematics Education, 8(1), 12-31. https://doi.org/10.30935/scimath/9544

Vogler, J. S., Thompson, P., Davis, D. W., Mayfield, B. E., Finley, P. M., \& Yasseri, D. (2018). The hard work of soft skills: augmenting the project- based learning experience with interdisciplinary teamwork. Instructional Science, 46(3), 457-488. https://doi.org/10.1007/s11251-017-9438-9

Warr, M., \& West, R. E. (2020). Problem-based Learning Problem-based Learning Bridging Academic Disciplines with Interdisciplinary Project-based Learning: Challenges and Opportunities. The Interdisciplinary Journal of Problem-Based Learning, 14(1), 1-23. https://doi.org/10.14434/ijpbl.v14i1.28590

Wu, L., Warschauer, M., Fischer, C., \& Washington, G. (2020). Increasing success in college: Examining the impact of a project-based introductory engineering course. Journal of Engineering Education, 109(January), 384-401. https://doi.org/10.1002/jee.20319

Yusri. (2018). The Effects of Problem Solving, Project- Based Learning, Linguistic Intelligence and Critical Thinking on the Students' Report Writing. Advances in Language and Literary Studies, 2, 21-26. https://doi.org/10.7575/aiac.alls.v.9n.6p.21

\section{Copyrights}

Copyright for this article is retained by the author(s), with first publication rights granted to the journal.

This is an open-access article distributed under the terms and conditions of the Creative Commons Attribution license (http://creativecommons.org/licenses/by/4.0/). 